\title{
New species of Lessingianthus (Asteraceae, Vernonieae) from Brazil and Paraguay
}

\author{
M. Dematteis ${ }^{1}$, M.B. Angulo ${ }^{1}$
}

Key words

Compositae

new species

South America

taxonomy

Vernonia

\begin{abstract}
Two new species of the genus Lessingianthus (Vernonieae, Asteraceae) from Brazil and Paraguay are described and illustrated. Lessingianthus cipoensis is characterized by the presence of solitary heads disposed in short branches and ovate to elliptical leaves. It has a certain resemblance to $L$. vestitus, which has more branched inflorescences, with long branches, and lanceolate to obovate-lanceolate leaves. Lessingianthus paraguariensis is closely related to $L$. asteriflorus and $L$. mollissimus, but it can be distinguished by the broadly elliptical leaves and the large size of the outer phyllaries.
\end{abstract}

Published on 16 July 2012

\section{INTRODUCTION}

The genus Lessingianthus H.Rob. (Vernonieae, Asteraceae) comprises around 120 species widely distributed in Venezuela, Colombia, Peru, Brazil, Bolivia, Paraguay, Argentina and Uruguay (Robinson 1988). Lessingianthus was initially established to accommodate the species originally arranged under Vernonia Schreb. sect. Lepidaploa (Cass.) DC. ser. Macrocephalae Benth. \& Hook. (Bentham \& Hooker 1873). Almost all the species are perennial herbs, with medium or large-sized heads and seriate-cymose inflorescences (Dematteis 2006).

Lessingianthus can be distinguished from the remaining American members of the tribe by its non-glandular anther appendages, lack of basal style node and quadrate raphids in the achene wall (Robinson 1999). The genus is distinguished also by the surface morphology of the pollen grains and the basic chromosome number. The pollen grains have been called type "B" by Keeley \& Jones (1979) and they are tricolporate, echinolophate, with a discontinuous tectum, germinal furrows very long, converging at poles and lacunae disposed in a regular pattern, lacking a polar lacuna (Angulo \& Dematteis 2010). The basic chromosome number of the genus is $x=16$, differing from the majority of the American Vernonieae with a base of $x=17$ (Dematteis 2002).

Following the segregation of Lessingianthus (Robinson 1988), the only modification has been the transference of Lessingianthus subgen. Oligocephalus H.Rob. to the genus Chrysolaena H.Rob. (Dematteis 2007). In addition, several species still included in Vernonia have been transferred and new ones were described (Díaz-Piedrahita \& Obando 2002, Dematteis 2006, 2008, Dematteis \& Angulo 2010). In the present paper two new species of Lessingianthus from Brazil and Paraguay are described and illustrated.

\section{MATERIALS AND METHODS}

Pollen samples were obtained by removing one or two florets from herbarium specimens of the species. The pollen grains

\footnotetext{
Instituto de Botánica del Nordeste (UNNE-CONICET), Casilla de Correo 209, 3400 Corrientes, Argentina;
}

corresponding author e-mail: mdematteis@agr.unne.edu.ar. were acetolysed according to the procedure suggested by Erdtman (1966). For light microscopy (LM) the pollen samples were mounted in glycerine-jelly on glass slides and then examined with a Zeiss Axioplan microscope. Permanent slides were deposited at the Palynological Laboratory of the Universidad Nacional del Nordeste (PAL-CTES). For scanning electron microscopy (SEM), acetolysed pollen grains were first washed in $96 \%$, and then $100 \%$ alcohol, next sputtered with goldpalladium and then observed in a JEOL 5800 LV scanning electron microscope. The terminology applied for pollen grain description in general follows Erdtman (1966) and Punt et al. (2007).

To examine micro-characters, florets were obtained from herbarium specimens and softened in boiling water to which a drop of detergent was added, dissected under a stereomicroscope, mounted in Hoyer's solution (Anderson 1954) and studied with a light microscope.

\section{DESCRIPTIONS}

\section{Lessingianthus cipoensis Dematt., sp. nov. - Fig. 1, 3a-c}

Lessingiantho vestito simile sed capitulis latioribus et folis brevioribus differt. Frutex erectus, caulibus lanatus dense foliatis. Inflorescentiae cymosa, ramis 4-5, erectis. Capitula sessilia, solitaria, late campanulata, 9-11 mm altae. - Typus: G. Hatschbach 30041 (holo MBM), Brazil, Minas Gerais, Mun. Jaboticatuba, Serra do Cipó, orla matinha de galeria, capítulos lilás, ereta, $50 \mathrm{~cm}$ alt., 7 Aug. 1972.

Erect shrub, 50-70 cm tall. Stems rounded, densely whitetomentose, leafy to the inflorescence, 3-5 $\mathrm{mm}$ diam., internodes $1-2 \mathrm{~cm}$ along all the stem. Leaves alternate to subopposite, sessile, dense, ascending, coriaceous, 25-35 by $14-18 \mathrm{~mm}$. Leaf blades ovate to elliptical, entire to denticulate, basally subcordate, acute at the apex, smooth and laxly lanate above, veins impressed, densely lanate beneath, pinnatinervate, secondary veins $4-5$, slightly arcuate. Inflorescence seriate-cymose, erect, branches $4-5$, short, with 2-3 heads. Bracts of the inflorescence leafy, densely lanate, larger than the heads or equal. Capitula sessile. Involucre widely campanulate, $9-11 \mathrm{~mm}$ high, $8-10 \mathrm{~mm}$ diam. Phyllaries 6-7 seriate, imbricate, appressed, acuminate, densely lanate, inner phyllaries ovate-lanceolate to linear, $7-8$ by $1-1.5 \mathrm{~mm}$, 


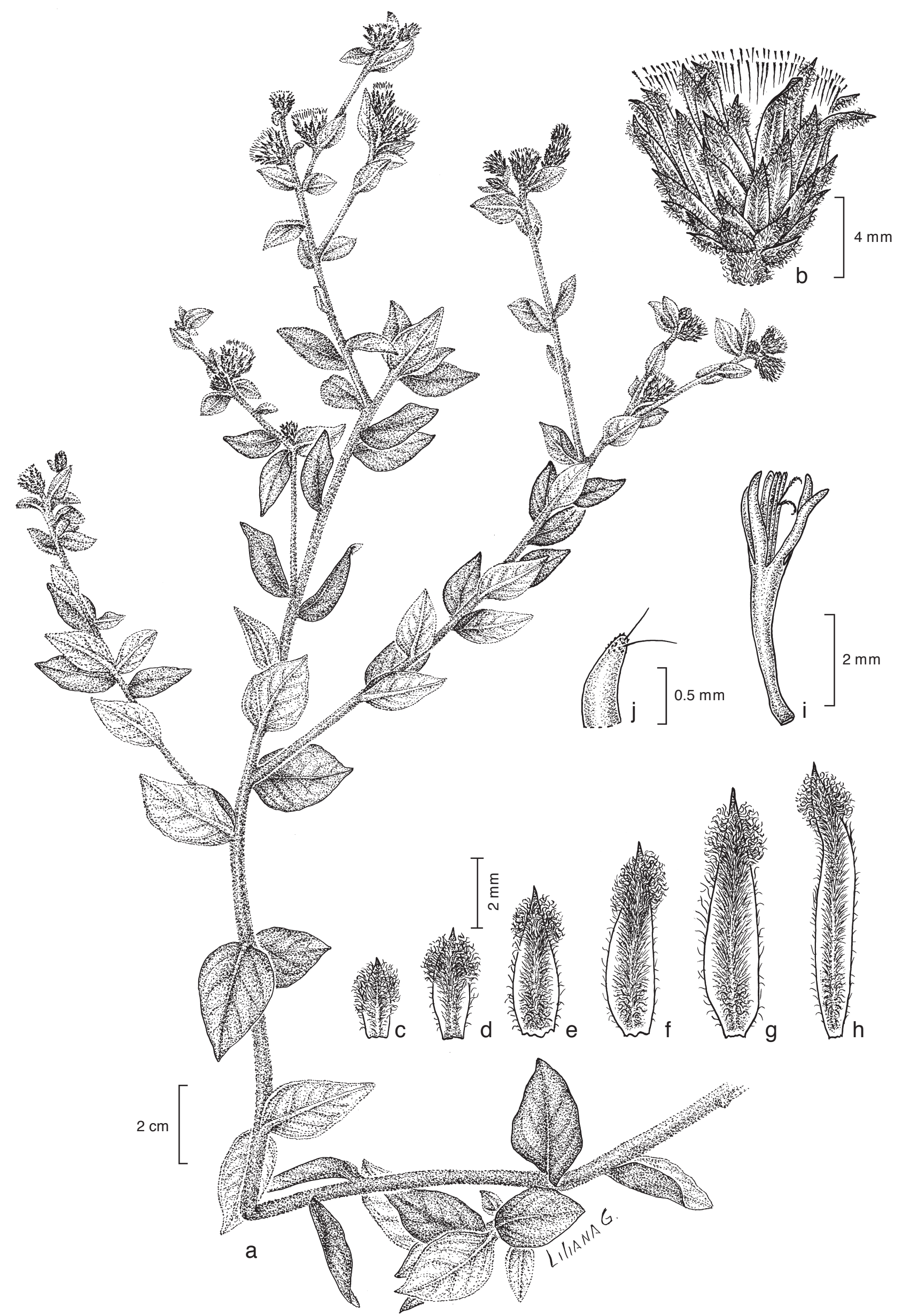

Fig. 1 Lessingianthus cipoensis Dematt. a. Flowering branch; b. capitulum; c, d. outer phyllaries; e, f. middle phyllaries; g, h. inner phyllaries; i. corolla showing anthers; j. corolla lobe (all: Hatschbach 30041, MBM). 


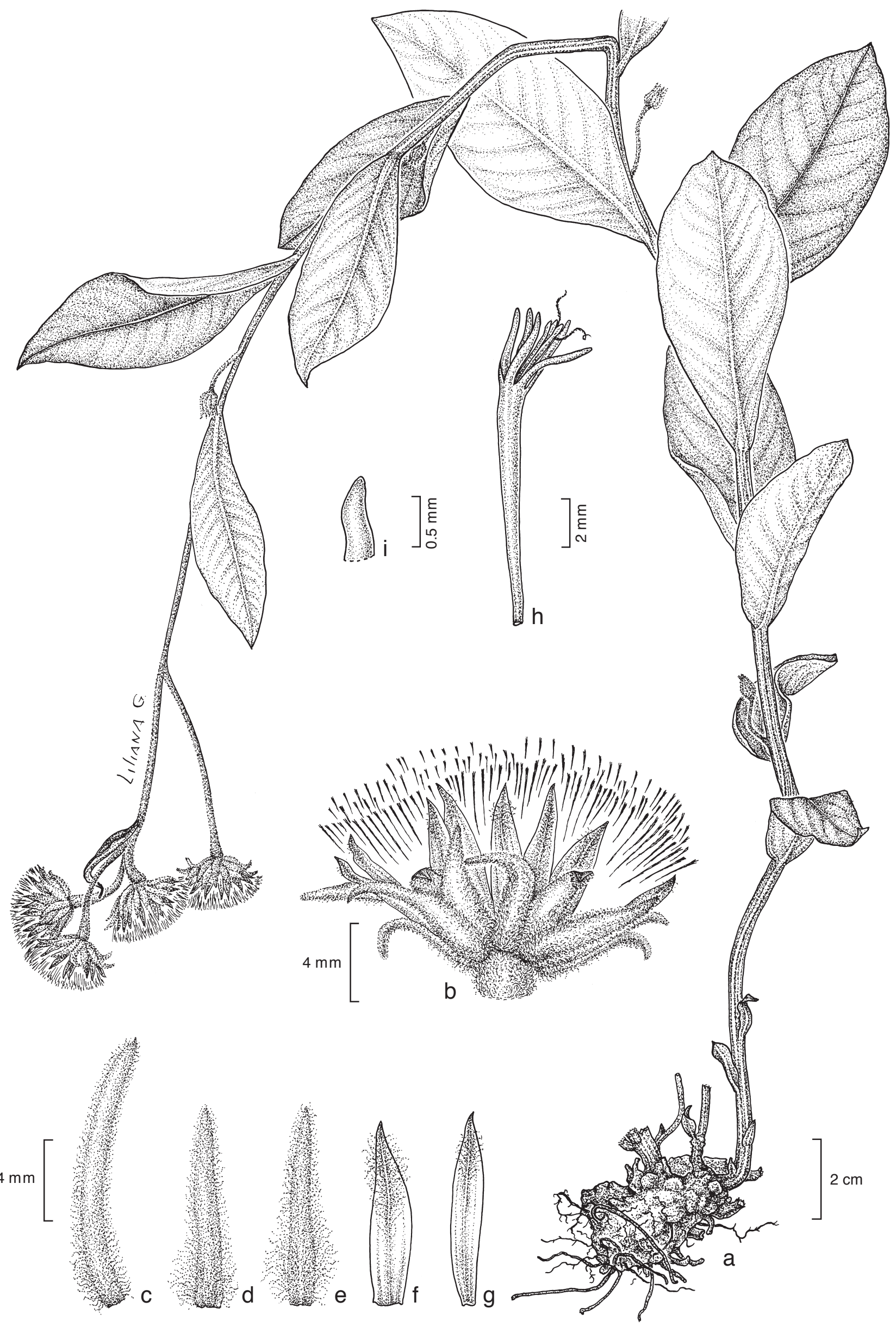

Fig. 2 Lessingianthus paraguariensis Dematt. a. Plant; b. capitulum; c, d. outer phyllaries; e. middle phyllary; f, g. inner phyllaries; h. corolla showing anthers; i. corolla lobe (all: Schinini, Dematteis, Duré \& Quintana 35897, CTES). 
middle phyllaries ovate-lanceolate, $3-5$ by $1-1.2 \mathrm{~mm}$, outer ones ovate, $2-3.5$ by $0.7-1 \mathrm{~mm}$. Florets violet. Corollas $6-8$ $\mathrm{mm}$ long, lobes lanceolate, $2.5-3 \mathrm{~mm}$ long, glandular, laxly pilose at the apex. Anthers basally calcarate, thecae 3.2-3.6 $\mathrm{mm}$ long, apical appendages ovate, $0.3-0.4 \mathrm{~mm}$ long. Style 9-10 mm long, branches linear, 1.5-1.8 mm long. Cypselas obconical, ribbed, densely sericeous pubescent, 2-2.5 mm long, with idioblasts and prismatic crystals in the wall. Pappus biseriate, greyish, inner bristles $6-7 \mathrm{~mm}$ long, outer scales linear-lanceolate, fimbriate, $1.6-1.8 \mathrm{~mm}$ long. Pollen grains oblate-spheroidal $(\mathrm{P} / \mathrm{E}=0.99)$, tricolporate, echinolophate, germinal furrows very long, converging at poles. Polar diam. 59.84-(61.2)-62.56 $\mu \mathrm{m}$, equatorial axis 59.8-(61.8)-63.9 $\mu \mathrm{m}$. Exine, excluding the spines, 8.2-8.4 $\mu \mathrm{m}$ thickness. Lacunae 12.2-14.9 $\mu \mathrm{m}$ diam., disposed in a regular pattern, polar lacuna absent. Spines 2.5-3.9 long with apex acute.

Distribution - The new species is only distributed in the Brazilian state of Minas Gerais.

Habitat \& Ecology - In gallery forest and campo cerrado habitats.

Additional specimens examined. BrazIL, Minas Gerais, BR 267, km 207, $4 \mathrm{~km}$ depois de Bom Jardim de Minas, indo para Juiz de Fora, campo de altitude ao lado da estrada, subarbusto de aproximadamente $50 \mathrm{~cm}$, com flores magenta e com frutos, 2 Feb. 1998, J.H.A. Dutilh \& W. Marcondes Ferreira 35 (CESJ)

Note - Lessingianthus cipoensis bears a resemblance to L. vestitus (Baker) H.Rob., but can be separated by its shorter and less branched inflorescence, acuminate phyllaries, ovate leaves and leaf blades $2.5-3.5 \mathrm{~cm}$ long. Lessingianthus vestitus has more branched inflorescences, with long branches, acute phyllaries, lanceolate to obovate-lanceolate leaves and leaf blades $10-15 \mathrm{~cm}$ long. The new species is also related to L. lacunosus (Mart. ex DC.) H.Rob., which has stems lanate, lanceolate leaves, phyllaries $5-6$ seriate and leaf blades ru- gulose above. Lessingianthus cipoensis has stems tomentose, leaves ovate to elliptical, phyllaries $6-7$ seriate and leaf blades smooth on the adaxial surface.

\section{Lessingianthus paraguariensis Dematt., sp. nov. - Fig.} $2,3 d-f$

Lessingiantho asterifloro simile sed capitulis solitaris et phyllaris aequo longibus differt. Frutex erectus, caulibus gracilibus laxe foliatis. Inflorescentiae cymosa, ramis $2-3$, erectis. Capitula sessilia, solitaria, hemisphaerica, 10-13 mm altae. - Typus: A. Schinini, M. Dematteis, R. Duré \& M. Quintana 35897 (holo CTES; iso G, PY), Paraguay, Amambay, 27 km N de P.J. Caballero, $\mathrm{S} 22^{\circ} 21^{\prime} 05^{\prime \prime}, \mathrm{W} 55^{\circ} 55^{\prime} 24^{\prime \prime}$, en campos cerrados, suelo arenoso, quemados de la Sierra de Amambay, semi erecta, flores violáceas, follaje discolor, envés blanquecino, 6 Mar. 2002.

Erect shrub, 50-80 $\mathrm{cm}$ tall. Stems $2-3$, striate, laxly leafy, densely tomentose, whitish, $3.5-4.5 \mathrm{~mm}$ diam. at the base, basal internodes $10-15 \mathrm{~cm}$ long, middle internodes $2-3 \mathrm{~cm}$ long. Leaves alternate, sessile, coriaceous, discolour, the greatest $6-8$ by $3-4 \mathrm{~cm}$, placed on the middle portion of the stem. Leaf blades broadly elliptic, entire, acute at the apex, obtuse at the base, glabrous or scarcely lanate above, white-tomentose beneath, pinnatinervate, secondary veins $10-15$, scarcely curved. Bracts of the inflorescence absent. Inflorescence corymbiform, erect, with 2-4 heads. Capitula pedunculate, peduncles 10-15 $\mathrm{mm}$ long, tomentose. Involucre hemispherical, 10-12 $\mathrm{mm}$ high, 15-17 mm diam. Phyllaries $2-3$ seriate, laxly imbricate, the outer ones linear to linear-lanceolate, acute, densely tomentose, $10-15$ by $1-1.5 \mathrm{~mm}$, inner phyllaries lanceolate, acute to acuminate, glabrous to apically tomentose, $8-10$ by $1.6-2$ $\mathrm{mm}$. Florets purple to violet. Corollas glabrous, 13-14 mm long, lobes lanceolate, $4-4.5 \mathrm{~mm}$ long, papilose at apex, with small glandular and eglandular hairs. Anthers basally caudate, 3.8-4 $\mathrm{mm}$ long, apical appendage ovate, $0.4-0.45 \mathrm{~mm}$ long. Style 14-15 mm long, branches linear, 3-3.5 mm long. Cypselas
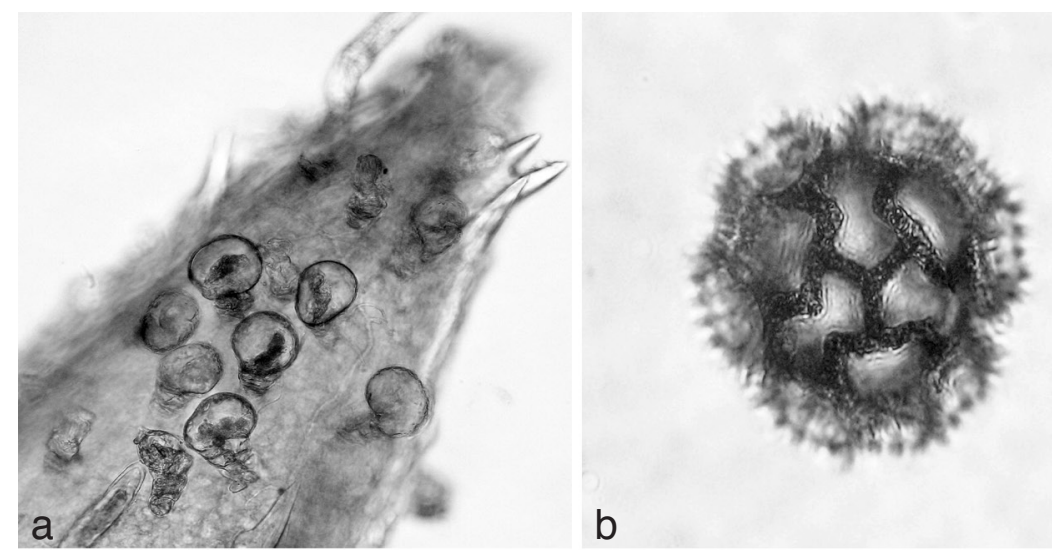

b

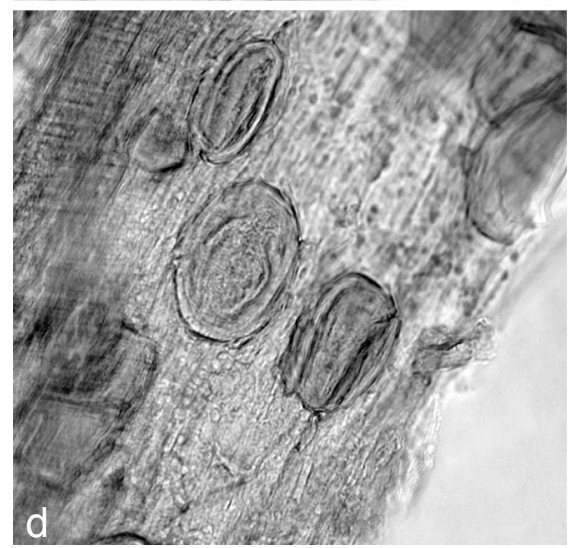

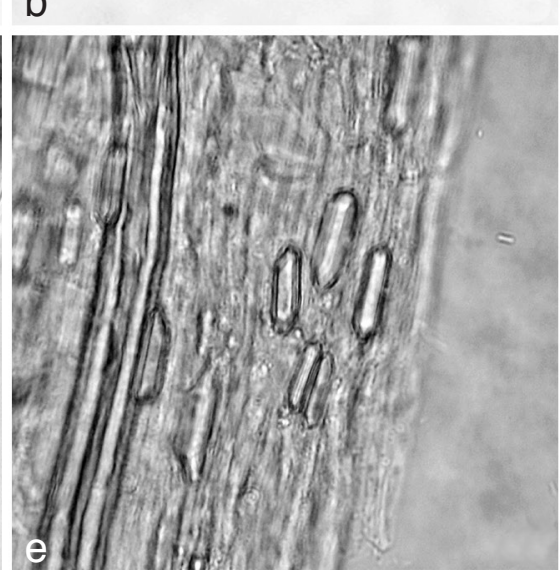

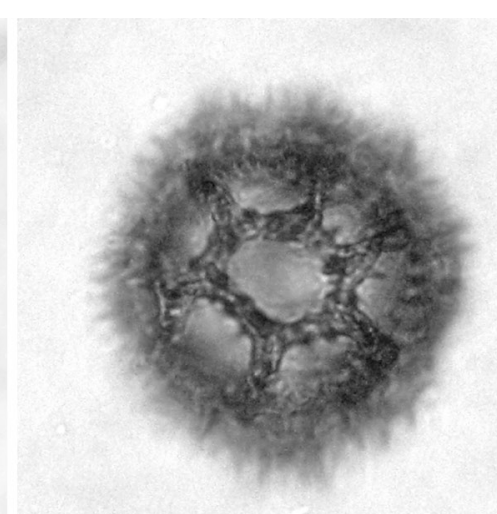

C

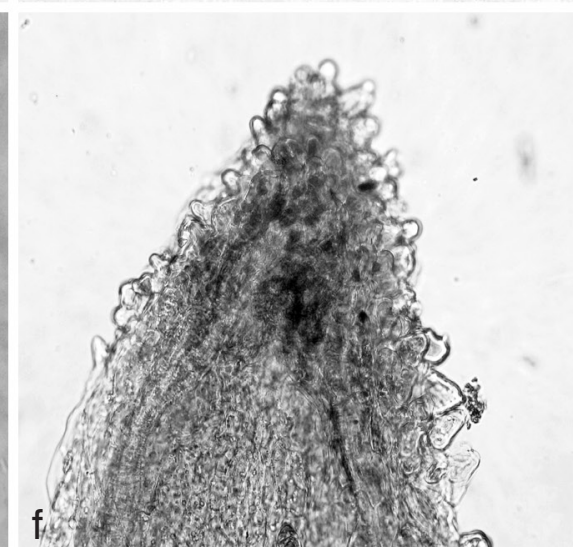

Fig. 3 Microcharacters and pollen grains of the new species. a-c. Lessingianthus cipoensis; a. corolla lobe apex; b. pollen grain, polar view; c. pollen grain, equatorial view; d-f. L. paraguariensis; d. idioblasts; e. crystals of the achene wall; f. corolla lobe apex (a-c: Hatschbach 30041, MBM; d-f: Schinini et al. 35897, CTES). 
ribbed, laxly sericeous, densely covered of idioblast, raphides quadrangular to prismatic, 3.3-3.5 mm long. Pappus white, biseriate, outer scales fimbriate, irregular, 1.2-2.1 mm long, inner bristles 9-10 mm long. Pollen grains oblate-spheroidal $(\mathrm{P} / \mathrm{E}=0.98)$, 3-colporate, echinolophate. Colpi long, with apices visible in polar view. Polar diam. 47.6-(48.4)-48.9 $\mu \mathrm{m}$, equatorial axis 48.9-(49.3)-50.3 $\mu \mathrm{m}$. Exine thickness 5.1-5.3 $\mu \mathrm{m}$. Tectum discontinuous. Lacunae 10-12 $\mu \mathrm{m}$ diam., disposed in a regular pattern, polar lacuna absent. Tectum surface densely microperforate and spinose; spines $2.8 \mu \mathrm{m}$ long, acute at apex.

Distribution - Paraguay (Amambay).

Habitat \& Ecology — In campo and on grassy savannas with dry, rocky soils. Flowering and fruiting in January and March.

Etymology - The specific epithet refers to the region where the species occur.

Additional specimens examined. PARAguAY, Amambay, in altoplanitie et declivibus Sierra de Amambay, Jan. 1907/1908, T. Rojas 10060 (BM, G).

Note - Lessingianthus paraguariensis is closely related to L. asteriflorus (Mart. ex DC.) H.Rob. and L. mollissimus (D.Don) H.Rob., but it can be distinguished by the broadly elliptical leaves and the size of the outer phyllaries, larger than the inner ones. Lessingianthus asteriflorus and L. mollissimus have lanceolate to oblong-lanceolate leaves and outer phyllaries shorter than the inner ones. In addition, the new species has the larger leaves in the middle portion of the stem, while $L$. asteriflorus and $L$. mollissimus have the larger leaves at the base of the stems.

Acknowledgements We are grateful to the curators and staff of the examined herbaria for their collaboration and loans of specimens. Thanks to Mirtha Liliana Gómez for preparing the line drawings. This work has been supported by grants from Consejo Nacional de Investigaciones Científicas y Tecnológicas (CONICET), Secretaría General de Ciencia y Técnica de la Universidad Nacional del Nordeste (SGCyT-UNNE) and the Myndel Botanica Foundation, which are greatly appreciated.

\section{REFERENCES}

Anderson LE. 1954. Hoyer's solution as a rapid mounting medium for bryophytes. Bryologist 57: 242-247.

Angulo MB, Dematteis M. 2010. Pollen morphology of the South American genus Lessingianthus (Vernonieae, Asteraceae) and its taxonomic implications. Grana 49, 1: 12-25.

Bentham G, Hooker JD. 1873. Vernonieae. Genera Plantarum. Reeve \& Co., London.

Dematteis M. 2002. Cytotaxonomic analysis of South American species of Vernonia (Vernonieae: Asteraceae). Botanical Journal of the Linnean Society 139: 401-408.

Dematteis M. 2006. New species of Lessingianthus (Asteraceae, Vernonieae) from Central Brazil. Blumea 51: 299-304.

Dematteis M. 2007. Taxonomic notes on the genus Chrysolaena (Vernonieae, Asteraceae), including a new species endemic to Paraguay. Annales Botanici Fennici 44, 1: 56-64.

Dematteis M. 2008. New species and new combinations in the South American genus Lessingianthus (Vernonieae, Asteraceae). Edinburgh Journal of Botany 65: 359-368.

Dematteis M, Angulo MB. 2010. Additions to the genus Lessingianthus (Vernonieae, Asteraceae) from South America. Rodriguésia 61, 2: 233-241.

Díaz-Piedrahita S, Obando S. 2002. Novedades en Vernonieae (Asteraceae) de Colombia. Revista de la Academia Colombiana de Ciencias Exactas 26: 347-351.

Erdtman, G. 1966. Pollen morphology and plant taxonomy. Angiosperms. Hafner, New York.

Keeley SC, Jones SB. 1979. Distribution of the pollen types in Vernonia (Vernonieae: Asteraceae). Systematic Botany 4: 195-202.

Punt W, Hoen PP, Blackmore S, Nilsson S, Le Thomas A. 2007. Glossary of pollen and spore terminology. 2nd rev. ed. LPP Foundation, Utrecht.

Robinson H. 1988. Studies in the Lepidaploa complex (Vernonieae: Asteraceae). IV. The new genus Lessingianthus. Proceedings of the Biological Society of Washington 100: 929-951.

Robinson H. 1999. Generic and subtribal classification of American Vernonieae. Smithsonian Contributions to Botany 89: 1-116. 